\title{
STRATEGI PEMASARAN DESTINASI WISATA AIR PANAS WATERBOOM SULILI KABUPATEN PINRANG DI MASA COVID 19
}

\author{
Suardi \\ Politeknik Pariwisata Makassar \\ Email: suardipoltekpar@gmail.com
}

\begin{abstract}
This study aims: to explained the marketing strategy by manager of hot water tourism Sulili Waterboom Pinrang Regency to development of tourism destination potency in Covid 19 Era, and to implementation the marketing strategy by manager of hot water tourism Sulili Waterboom Pinrang Regency to development of tourism destination potency in Covid 19 Era. The analytical method used: the quantitative and qualitative method which source from primary and secondary data. The technique of data gathered include interview, observation, library research and documentation. Data obtained it to arrangement and preparation and analysis with used of qualitative descriptive such as the explained then to analysis and naration. The results of this study indicate: the manager of hot water tourism Sulili Waterboom Pinrang Regency applied of marketing strategy STP as the important strategy to increasingthe local and national tourism visiting come to Pinrang Regency for holiday and recreation which have contribution to increased the regional income. The pandemic Covid 19 era the total tourism visiting to decreasing, cause it require to applied of seriously attempt from management parties to commitment applied of marketing strategy STP which reorientation to increased the segmentation of local or national tourist, with marketing target for general visitor from all of ages and to become the positition of Waterboom Tourism Destination as the main of tourism visiting in Pinrang Regency.
\end{abstract}

Keywords: marketing strategy, segmentation, targeting, positioning, hot water tourism sulili waterboom

\section{PENDAHULUAN}

Negara Republik Indonesia merupakan Negara yang memiliki potensi sumber daya alam yang berlimpah, keanekaragaman hayati dan peninggalan sejarah/budaya. Berlimpahnya sumber daya alam yang ada dapat meningkatkan 
pertumbuhan ekonomi ketika sumber daya tersebut dapat di kelola dengan baik sesuai dengan apa yang paling diminati masyarakat sehingga pemanfaatan sumber daya alam tersebut tidak akan menghabiskan waktu ataupun materi akibat ketidakberhasilan dalam mengelola suatu sumber daya.

Pariwisata merupakan salah satu pemanfaatan sumber daya alam yang dapat bernilai ekonomi tinggi bagi suatu daerah yang mengelola sumber daya alam menjadi suatu tempat wisata yang menarik pengunjung baik dari dalam maupun dari luar negeri, disamping bernilai ekonomi yang tinggi, pariwisata dapat menumbuhkan dan meningkatkan rasa bangga terhadap bangsa sehingga akan tumbuh masyarakat yang lebih peduli terhadap suatu bangsa. Pariwisata adalah hal yang diminati oleh setiap individu, karena dapat menghilangkan kejenuhan, berkembangnya kreativitas dan mampu menunjang produktivitas suatu individu.

Dasar hukum pengembangan pariwisata yang sesuai dengan prinsip pengembangan menurut Undang-Undang RI Nomor 10 Tahun 2009 tentang Kepariwisataan (Pasal 6: Pembangunan kepariwisataan dilakukan berdasarkan asas sebagaimana dimaksud dalam Pasal 2 yang diwujudkan melalui pelaksanaan rencana pembangunan kepariwisataan dengan memperhatikan keanekaragaman, keunikan, dan kekhasan budaya dan alam, serta kebutuhan manusia untuk berwisata). Pasal 8 yaitu: 1) Pembangunan kepariwisataan dilakukan berdasarkan rencana induk pembangunan kepariwisataan yang terdiri atas rencana induk pembangunan kepariwisataan nasional, rencana induk pembangunan kepariwisataan provinsi, dan rencana induk pembangunan kepariwisataan kabupaten/kota; 2) Pembangunan kepariwisataan sebagaimana dimaksud pada ayat (1) merupakan bagian integral dari rencana pembangunan jangka panjang nasional. Pasal 11 : Pemerintah bersama lembaga yang terkait dengan kepariwisataan menyelenggarakan penelitian dan pengembangan kepariwisataan untuk mendukung pembangunan kepariwisataan.) serta Pasal 12 ayat (1) aspekaspek penetapan kawasan strategis pariwisata.

Dalam era globalisasi sekarang ini, bidang pariwisata merupakan salah satu kegiatan yang mempunyai peranan yang sangat strategis dalam menunjang pembangunan perekonomian nasional. Sektor ini dicanangkan selain sebagai salah satu sumber penghasil devisa yang cukup andal, juga merupakan sektor yang mampu menyerap tenaga kerja dan mendorong perkembangan investasi. Untuk mengembangkan sektor ini pemerintah berusaha keras membuat rencana dan berbagai kebijakan yang mendukung kearah kemajuan sektor ini. Salah satu kebijakan tersebut adalah menggali, menginventarisir dan mengembangkan obyek-obyek wisata yang ada sebagai daya tarik utama bagi wisatawan. Namun hal tersebut mengalami penurunan di masa Covid 19, di mana pemberlakuan himbauan Pembatasan Sosial Berskala Besar (PSBB), menyebabkan jumlah kunjungan wisata menurun ke tempat destinasi. 
Kabupaten Pinrang memiliki potensi di sektor pariwisata. Kabupaten ini memiliki peninggalan sejarah yang tercatat dan sangat menarik untuk dikunjungi. Tak heran memang jika pemerintah kabupaten setempat sangat menaruh perhatian terhadap pariwisata. Pembangunan kepariwisataan pada hakekatnya merupakan upaya untuk mengembangkan dan memanfaatkan obyek dan daya tarik wisata yang terwujud antara lain dalam bentuk kekayaan alam yang indah, keragaman flora dan fauna, kemajemukan tradisi dan seni budaya, dan peninggalan purbakala.

Observasi awal yang dilakukan penulis di masa pandemi Covid 19 terlihat destinasi Wisata Air Panas Waterboom Sulili sepi dari pengunjung, bahkan ditutup untuk umum, guna mempersiapkan destinasi wisata menuju new normal. Kondisi destinasi di masa pandemi banyak petugas atau karyawan yang dirumahkan untuk sementara waktu, sarana prasarana yang tersedia tidak difungsikan seperti pada kondisi normal, sehingga terlihat banyak dedaunan kering yang berserakan di tempat destinasi tersebut yang memberi kesan kurang menarik dan area foodcourt tidak terurus karena tidak menjual jajanan untuk pengunjung.

Berdasarkan data jumlah kunjungan wisatawan di Wisata Air Panas Waterboom Sulili Kecamatan Paleteang Kabupaten Pinrang pada tahun 2018 sebanyak 8.583 orang mengalami penurun menjadi 7.869 ditahun 2019 apalagi ditahun 2020 bersamaan dengan merebaknya pedemik Covid-19 tentu akan mengalami penurunan lagi. Objek wisata alam menjadi alternatif pilihan konsumen untuk rekreasi dan menghabiskan waktu luang. Usaha objek wisata alam semakin banyak dikembangkan untuk memenuhi permintaan masyarakat akan kebutuhan rekreasi. Potensi pengembangan usaha objek wisata alam di Kabupaten Pinrang cukup tinggi dan memilki prospek yang cukup bagus di masa yang akan datang karena ditunjang oleh potensi daerah yang baik dengan kondisi alam yang berudara segar serta dukungan yang sangat besar dari Pemerintah Daerah Kabupaten Pinrang terkait pengembangan dunia pariwisata.

Pengembangan Destinasi Wisata Air Panas Waterboom Sulili pada masa mendatang, diperlukan sebuah perubahan paradigma pengusahaan wisata alam yang berorientasi pada kepuasan pelanggan/ Customer Service Oriented (CSO) sehingga pihak pengelola maupun pihak pengusaha harus mengetahui berbagai keinginan konsumen pada saat berkunjung ke lokasi wisata, sehingga pelayanan yang diberikan oleh pihak pengusahaan sesuai dengan harapan pengunjung yang datang.

Fasilitas Waterboom Sulili Kabupaten Pinrang saat ini mengandalkan beberapa fasilitas baru dan spot foto yang instagramable (layak ditampilkan di instragram sosial media) yang kini telah beroperasi sebagai salah satu sarana hiburan yang murah dan memiliki fasilitas yang memadai. Dulunya fasilitas wisata ini hanya sebagai permandian alam kini telah bertransformasi menjadi 
sarana hiburan yang modern dan ramah lingkungan dan ramah pengunjung pada semua rentang umur.

Paradigma kunjungan wisata menjadi pertimbangan utama bagi pemerintah untuk menghidupkan atau mengembangkan potensi destinasi wisata Waterboom Sulili yang siap dan layak dikunjungi di masa Covid 19, karena itu pemerintah daerah dan pengelola destinasi telah membuka kembali secara bertahap dengan mengikuti protokol kesehatan. Mewujudkan hal tersebut upaya gencar dilakukan adalah menjadikan destinasi ini sebagai wahana baru dan pengembira untuk keluarga yang datang berkunjung. Paradigma baru yang diterapkan yaitu menjadikan Waterboom Sulili sebagai destinasi utama wisata alam air panas di Kabupaten Pinrang, menjadi sumber PAD, membuka peluang kerja dan bisnis wisata serta menjadi sarana rekreasi masyarakat. Paradigma kunjungan wisata ini harus didukung oleh strategi pemasaran destinasi yang menerapkan grand theory konsep STP (Segmentasi, Targeting dan Positioning).

Manajemen strategi pemasaran adalah kunci utama suatu produk dan jasa mampu dikenal oleh masyarakat agar nantinya diharapkan mampu bersaing di pasar dan memenuhi kebutuhan/kepuasan pelanggan, sehingga dibutuhkan suatu perencanaan bagi destinasi wisata air panas Waterboom Sulili dalam memasarkan produk atau jasanya agar terlihat perbedaan di benak konsumen. Maka diperlukan suatu upaya kajian strategi pemasaran bagi destinasi Wisata Air Panas Waterboom Sulili dalam menghadapi persaingan pasar.

Grand theory strategi pemasaran yang dikemukakan Kotler dan Keller (2007:85) keberhasilan pemasaran jasa dan produk ditentukan oleh strategi STP (segmentation, targeting, positioning). Pengambil keputusan harus mengetahui tingkat segmentasi pasar tujuan, mampu menentukan capaian target pasar dan menentukan posisi pemasaran yang diterapkan. Aktualisasi dari teori strategi pemasaran ini dalam konsep pemasaran pariwisata, setiap pengelola destinasi harus menentukan segmen kunjungan wisata yang datang baik domestik maupun mancanegara, harus menentukan target jumlah kunjungan wisata setiap hari, minggu, bulan dan tahun, serta menentukan kelayakan posisi destinasi wisata yang ditawarkan berdasarkan wisata alam, atraksi wisata, kuliner, permandian, dan budaya.

Penjelasan di atas, perlu disadari oleh pemerintah daerah dalam hal ini Dinas Pariwisata Pemuda dan Olahraga yang sangat berperan penting dalam pengambilan kebijakan mengembangkan suatu objek wisata mengingat bahwa destinasi Wisata Air Panas Waterboom Sulili adalah salah satu tempat wisata yang mempunyai potensi yang sangat besar dalam menumbuhkan Pendapatan Asli Daerah (PAD). Solusi yang dimaksud dalam hal ini adalah strategi terkait dengan pengembangan destinasi agar dapat lebih berdaya saing dalam menarik wisatawan. Strategi sebagai bentuk upaya yang dilakukan untuk menciptakan dan melestarikan kawasan wisata dengan menggunakan dimensi strategi untuk menciptakan pemasaran pariwisata yang sesuai dengan pengembangan kawasan 
destinasi wisata. Sehingga dengan demikian pemerintah dapat mengambil langkah yang strategis dari pilihan yang ada.

Strategi pemasaran menjadi sangat penting bagi pengembangan destinasi wisata dalam rangka pencapaian tujuan, baik tujuan jangka pendek, menengah maupun jangka panjang. Kajian dalam pengembangan strategi pemasaran difokuskan pada konsep STP (segmentasi, targeting dan positioning) pada kasus destinasi wisata air panas Waterboom Sulili Kabupaten Pinrang di masa Covid 19. Oleh karena itu, penyusunan strategi pemasaran merupakan langkah taktis yang bersifat sistematis dalam pencapaian tujuan dunia kepariwisataan. Berdasarkan uraian sebelumnya, maka penulis tertarik untuk melakukan penelitian dengan judul: "Strategi Pemasaran Destinasi Wisata Air Panas Waterboom Sulili Kabupaten Pinrang di Masa Covid 19".

Strategi pemasaran yang bijak dan adil dalam pengelolaan destinasi Wisata Air Panas Waterboom Sulili yang layak untuk dipasarkan ke konsumen sebagai penikmat wisata maka perlu diberikan solusi berdasarkan permasalahan yang telah dirumuskan. Permasalahan dalam penelitian ini adalah "bagaimana strategi pemasaran untuk destinasi Wisata Air Panas Waterboom Sulili Kabupaten Pinrang di masa Covid 19 dalam upaya meningkatkan dan mempertahankan kunjungan melalui segmentasi, target dan posisi pasar, baik pada tingkat lokal maupun nasional". Tujuan yang ingin dicapai dalam artikel ini adalah

1. Menjelaskan strategi pemasaran yang dilakukan oleh pengelola Wisata Air Panas Waterboom Sulili Kabupaten Pinrang untuk mengembangkan potensi destinasi wisata di masa Covid 19.

2. Mengimplementasikan strategi pemasaran yang dilakukan pengelola Wisata Air Panas Waterboom Sulili Kabupaten Pinrang untuk mengembangkan potensi destinasi wisata di masa Covid 19.

\section{Pemasaran}

Kotler dan Keller (2007)mengungkapkan bahwapemasaran adalah proses perencanaan dan pelaksanaan konsepsi, penetapan harga, promosi, dan pendistribusian gagasan, barang dan jasa untuk menciptakan pertukaran yang mampu memenuhi tujuan individu dan organisasi. Pertukaran dalam konteks ini dimaksudkan sebagai sebuah proses dimana dua atau lebih pihak saling mempertukarkan sesuatu yang memiliki nilai sehingga pada akhirnya mereka merasa lebih baik setelah melakukan proses tersebut.

\section{Strategi Pemasaran}

Setiap perusahaan selalu berupaya agar apa yang dipasarkan dapat laku terjual di pasaran, hal ini juga untuk menjaga eksistensi dari perusahaan itu sendiri. Untuk mewujudkan hal tersebut maka diperlukan strategi yang baik dan tepat. Strategi pada hakikatnya adalah 
perencanaan (planning) dan manajemen (management) untuk mencapai suatu tujuan.Akan tetapi, untuk mencapai tujuan tersebut, strategi tidak berfungsi sebagai peta jalan yang hanya menunjukan arah saja, melainkan harus mampu menunjukan bagaimana taktik operasionalnya. (Effendy, 2003:32).

Kotler (2009:58) menyatakan bahwa strategi pemasaran dapat dilihat dari tiga strategi yang biasa dikenal dengan istilah strategi STP (segmentation, targeting, positioning). Bahwa dalam melakukan suatu pemasaran produk, selalu memerhatikan pentingnya daya saing (segmentation) yang dapat memenuhi target penjualan produk (targeting) tanpa mengabaikan tata letak dari suatu kegiatan pemasaran atau positioning. Ketiga strategi pemasaran ini menentukan berhasil tidaknya suatu kegiatan pemasaran.

\section{Segmentasi}

Segmentasi merupakan suatu usaha untuk meningkatkan ketepatan perusahaan. Titik awal dari pembahasan segmentasi adalah pemasaran massal. Argumen bagi pemasaran massal adalah menciptakan pasar potensial terbesar yang menghasilkan biaya yang lebih rendah dan menghasilkan harga yang lebih rendah atau marjin yang lebih tinggi. Segmen pasar terdiri dari kelompok besar yang dapat diidentifikasi dalam sebuah pasar dengan keinginan, daya beli, lokasi geografis, perilaku pembelian dan kebiasaan pembelian yang serupa.

\section{Sasaran/Targeting}

Setelah melakukan identifikasi segmen pasar, selanjutnya mengevaluasi beragam segmen dan memutuskan berapa banyak dan segmen mana yang akan dibidik. Dalam mengevaluasi segmen pasar yang berbeda (dalam hal ini penentuan pasar sasaran/targeting), perusahaan harus memerhatikan dua faktor yaitu daya tarik secara keseluruhan serta tujuan dan sumberdaya perusahaan.

\section{Positioning}

Menurut Milton (2006:88) "positioning product is the place your product occupies in consumers' minds relative to competing products. Think brand image, benefit promise, and competitive advantage. It's how you plan to compete in the marketplace. It's the reasons customers should buy your product, and not the competitors". Dengan kata lain positioning adalah bagaimana sebuah produk di mata konsumen yang membedakannya dengan produk pesaing. Dalam hal ini termasuk brand image, manfaat yang dijanjikan serta competitive advantage. Inilah alasan kenapa konsumen memilih produk suatu perusahaan bukan produk pesaing.

\section{Objek Wisata}

Pengertian objek wisata secara umum menurut Peraturan Pemerintah Republik Indonesia No. 24/1979, tentang penyerahan 
sebagian urusan pemerintah dalam bidang kepariwisataan pada Daerah Tingkat I adalah perwujudan dari pada ciptaan manusia, tata hidup, seni budaya, serta sejarah bangsa dan tempat atau keadaan alam yang mempunyai daya tarik wisata bagi wisatawan untuk dikunjungi.

Pariwisata

Pariwisata merupakan salah satu kegiatan dimana hampir seluruh individu pernah terlibat di dalamya pada kurun waktu tertentu. Karya wisata ke museum lokal, piknik ke taman kota, perjalanan mudik kembali ke kampung halaman, ziarah ke situs penting keagamaan, liburan keluarga menjelajahi tempat-tempat baru yang menarik atau bahkan kegiatan safari bisnis ke luar daerah, semua itu adalah bagian kecil dari spektrum pariwisata.

Wisatawan

Istilah pariwisata dan travel kadang-kadang digunakan bergantian. Padahal seperti yang telah disampaikan sebelumnya, tidak semua kegiatan travel adalah pariwista meskipun semua aktivitas pariwisata pasti akan melibatkan perjalanan. Hal ini mengakibatkan munculnya beberapa variasi istilah selain "wisatawan" yang awam digunakan untuk menggambarkan orang-orang yang bepergian dengan tujuan di luar tempat tinggal mereka sendiri dan tempat bekerja seperti "travellers", "excurtionist" dan "visitor".

\section{Destinasi Wisata}

Sejalan dengan semakin banyak dan beragamnya kebutuhan akan pariwisata maka begitu pula dengan destinasi wisata sebagai objek penting dari pariwisata. Destinasi wisata harus terus melakukan inovasi yang konstan tidak hanya secara fisik namun juga nilai-nilai yang ditawarkan. Hal ini berarti bahwa destinasi wisata, baik yang baru muncul ataupun yang sudah matang perlu melakukan reposisi di pasar untuk menciptakan produk dan layanan destinasi wisata yang baru, mempertahankan kunjungan ulang dan merangsang pengembangan pasar baru.

\section{METODE PENELITIAN}

Metode penelitian menurut (Sugiono, 2016) yaitu cara ilmiah untuk mendapatakan data yang valid dengan tujuan dapat ditemukan, dikembangkan , dan dibuktikan suatu pengetahuan tertentu sehingga dapat digunakan dalam mengantisipasi masalah. Penelitian ini merupakan penelitian kualitatif yang dilakukan di Dinas Kebudayaan dan Pariwisata Kabupaten Pinrang. Hal ini didasarkan karena instansi tersebut telah diberi kewenangan untuk melakukan pengelolaan objek Wisata Air Panas Waterboom Sulili Kabupaten Pinrang di masa Covid 19. Jenis data yaitu data kuantitatif dan kualitatif yang bersumber dari data primer dan data sekunder. Teknik pengumpulan data melalui 
wawancara, observasi, penelitian kepustaan dan dokumentasi. Analisis data menggunakan analisis deskriptif kualitatif berupa pemaparan yang kemudian dianalisis dan ditarasikan.

\section{HASIL DAN PEMBAHASAN}

Wisata Air Panas Waterboom Sulili adalah salah satu tempat wisata di Kabupaten Pinrang yang ramai dengan wisatawan pada hari biasa maupun hari libur. Tempat ini sangat indah dan menawarkan sensasi yang berbeda. Keindahan wisata Waterboom Pinrang mempunyai pesona keindahan yang sangat menarik untuk dikunjungi. Penduduk lokal daerah pinrang juga sangat ramah tamah terhadap wisatawan lokal maupun wisatawan asing.

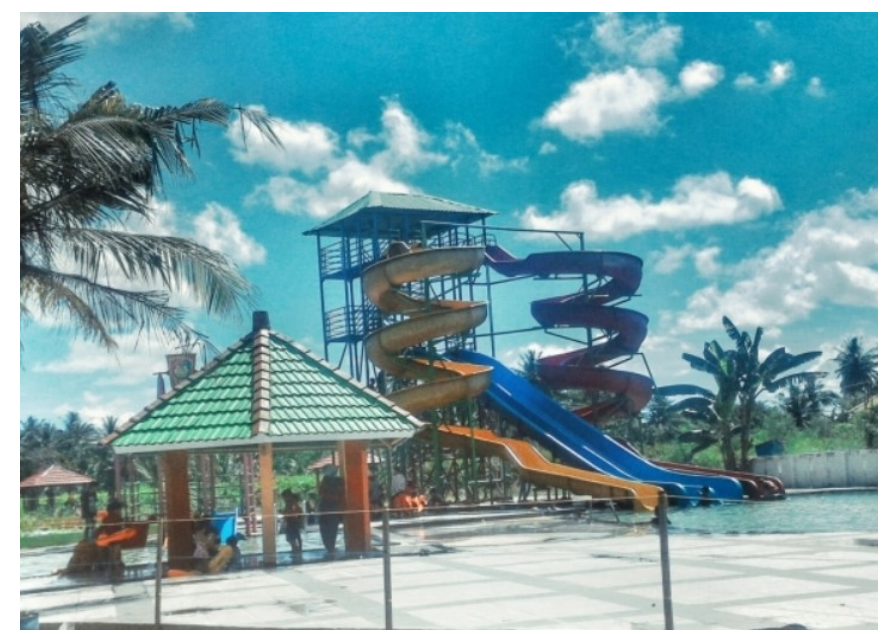

Gambar 1. Waterboom Sulili Kabupaten Pinrang

\section{Identifikasi Strategi Pemasaran}

Hasil penelitian mengenai strategi pemasaran untuk pengembangan potensi destinasi wisata air panas Waterboom Sulili di masa Covid 19 pada industri pariwisata sedang mengalami perkembangan pesat. Industri pariwasata merupakan industri tertua di dunia ini. Hal ini dibuktikan dengan banyaknya industri jasa objek wisata yang menawarkan pengalaman berwisata yang bermunculan khususnya di Indonesia. Selain itu, pemerintah pun sangat mendukung industri pariwisata, khususnya untuk turis asing yang ingin berwisata ke Indonesia bisa menimbulkan keuntungan untuk negara Indonesia sendiri. Sesuai dengan visi misi wisata air panas Waterboom Sulili ingin mengangkat sektor pariwisata taman wisata air di Kabupaten Pinrang, serta ingin meningkatkan sektor pariwisata Sulawesi Selatan, dengan menyediakan jasa tempat wisata air 
panas untuk keluarga yang nyaman, menyenangkan, dengan harga yang terjangkau.

\section{Strategi Segmentasi}

Strategi segmentasi dalam pemasaran dilakukan secara berkesinambungan dengan tujuan menunjang efektivitas dan efesiensi pemasaran suatu produk wisata. Dengan demikian segmentasi pemasaran memiliki peran penting dalam menjaga eksistensi perusahaan dengan banyaknya konsumen yang datang.

Berbagai langkah dilakukan oleh wisata air panas Waterboom Sulili di masa Covid 19 dalam membangun segmentasi dalam pemasarannya disusun kedalam suatu strategi komunikasi pemasaran. Strategi komunikasi pemasaran diharapkan membantu perusahaan untuk mengetahui seberapa besar keberhasilan yang telah dicapai. Strategi segmentasi pemasaran untuk mengidentifikasi segmen khalayak yang dituju, menentukan segmen tujuan yang ingin dicapai dan merancang segmen pasar yang tepat.

\section{Strategi Sasaran/Target}

Selanjutnya strategi sasaran atau target yang diterapkan perusahaan wisata air panas Waterboom Sulili melalui pemilihan saluran komunikasi yang tepat. Setelah merancang pesan, bagaimana pesan tersebut dapat tersampaikan dengan baik, maka diperlukan saluran komunikasi untuk menyampaikan pesan tersebut.

Memilih saluran komunikasi dapat dilakukan dengan saluran komunikasi personal yang mencakup dua orang atau lebih yang berkomunikasi secara langsung satu sama lain, dan juga dapat dilakukan dengan melalui media, atmosfer, atau acara, yang biasa disebut dengan sauran komunikasi nonpersonal, dimana menyampaikan pesan tanpa harus melakukan kontak atau interaksi pribadi.

\section{Strategi Posisi}

Strategi posisi yang diterapkan wisata air panas Waterboom Sulili di masa Covid 19 yaitu membuat keputusan bauran promosi (integrated marketing communication). Pada tahap ini, perusahaan akan memutuskan untuk mendistribusikan total anggaran yang sudah ditentukan untuk 6 alat promosi yang terdiri atas iklan, promosi penjualan, publisitas/ hubungan masyarakat, penjualan personal, pemasaran langsung, serta acara dan pengalaman.

Alur kegiatan pengunjung wisata air panas Waterboom Sulili dapat dilihat pada gambar 2 . 


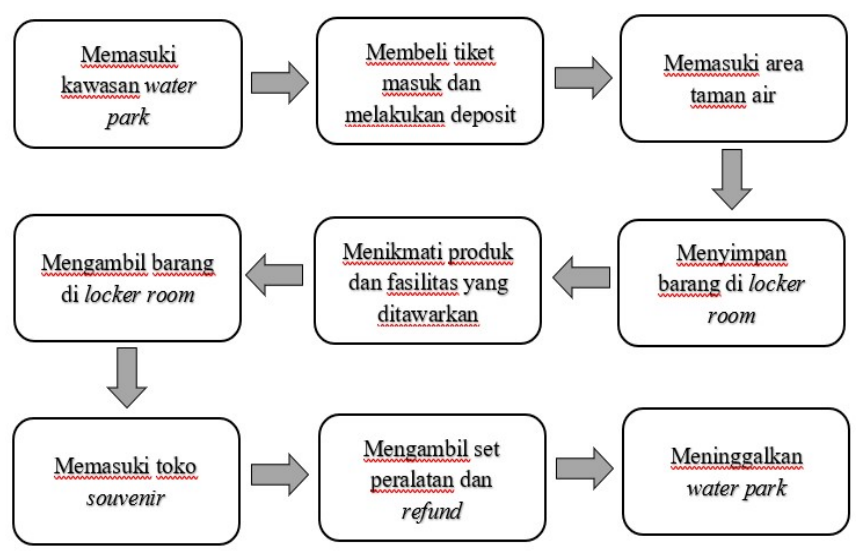

Gambar 2. Alur Kegiatan Pengunjung Wisata Air Panas Waterboom Sulili

Laporan anggaran pengeluaran marketing communication and promotion wisata air panas Waterboom Sulili dapat dilihat pada tabel 1.

Tabel 1. Data pengeluaran marketing communication and promotion wisata air panas waterboom sulili (Sumber: Waterboom Sulili, 2019)

\begin{tabular}{|c|l|r|}
\hline No. & \multicolumn{1}{|c|}{ Keterangan } & Biaya $(\mathrm{Rp})$ \\
\hline 1 & Pembuatan baliho & 5.500 .000 \\
2 & Pajak baliho (per tahun) & 1.500 .000 \\
3 & Spanduk & 1.500 .000 \\
4 & Flyer & 1.800 .000 \\
5 & SPB flyer & 300.000 \\
6 & Kegiatan bakti sosial & 10.000 .000 \\
7 & Kegiatan hari anak & 10.000 .000 \\
8 & Lomba panggung musik & 10.000 .000 \\
9 & Lomba anak-anak & 10.000 .000 \\
10 & Iklan media elektronik & 1.000 .000 \\
11 & Iklan media sosial & 1.000 .000 \\
12 & Merchandise & 500.000 \\
\hline \multicolumn{2}{|l|}{ Total Pengeluaran } & 53.100 .000 \\
\hline
\end{tabular}

Strategi pemasaran untuk pengembangan potensi destinasi wisata air panas Waterboom Sulili di masa Covid 19 diterapkan dengan melakukan pengelolaan dan pengkoordinasian strategi pemasaran yang terintegrasi. Dipahami bahwa dalam penerapan strategi pemasaran, banyak pengelola wisata masih sangat 
mengandalkan satu atau dua alat promosi untuk mencapai tujuan komunikasinya. Berkembangnya berbagai jenis media baru dan semakin canggihnya teknologi.

Melalui hasil penelitian maka dapat dipahami bahwa, strategi pemasaran wisata air panas Waterboom Sulili di masa Covid 19, mengintegrasikan antara push strategy dan pull strategy, dengan menggabungkan media serta penjualan langsung dan melalui acara-acara atau kegiatan humas sesuai protokol kesehatan, sebagai sarana mempromosikan produk wisata.

\section{SIMPULAN}

Berdasarkan hasil penelitian dan pembahasan, maka disimpulkan bahwa, Pengelola wisata air panas Waterboom Sulili menerapkan strategi pemasaran STP sebagai strategi penting untuk meningkatkan dan mempertahankan kunjungan wisata lokal maupun nasional untuk datang ke Kabupaten Pinrang berlibur dan berekreasi yang berkontribusi meningkatkan PAD. Di masa pandemi Covid 19 jumlah kunjungan wisata mengalami penurunan, karenanya perlu dilakukan upaya serius dari pihak manajemen untuk berkomitmen menerapkan strategi pemasaran STP secara reorientasi meningkatkan segmentasi jumlah pengunjung wisata lokal maupun nasional, dengan target pemasaran untuk umum dari segala batas umur dan menjadikan posisi destinasi wisata Waterboom sebagai tempat kunjungan wisata utama di Kabupaten Pinrang.

\section{DAFTAR PUSTAKA}

Effendy, O. U. (2011). Ilmu Komunikasi: Teori dan Prakteknya. Bandung: Remaja Rosdakarya.

Kotler P, dan Keller KL. 2007. Manajemen Pemasaran. Edisi ke-12. Jilid 1. Molan, penerjemah. Jakarta : PT Indeks. Terjemahan dari: Marketing Management.

Kotler, Philip, 2009. Manajemen Pemasaran, Analisis Perencanaan, Implementasi dan Kontrol. Edisi 9 PT. Prenhallindo, Jakarta.

Kotler, Philip, 2009. Manajemen Pemasaran. Edisi 1 dan 2. Penerbit Prenhallindo, Jakarta.

Kotler, Philip, 2009. Marketing Management. The Millennium Edition, Ten Edition, Prentice Hall., Inc, New York.

Milton, William, 2006. Marketing and Strategy in Marketing. McMillan, Canada. Sugiono, S. (2016). Metode penelitian kuantitatif, kualitatif, dan $\mathbf{r} \&$ d. Bandung: Alfabeta.

Undang-Undang Republik Indonesia Nomor 10 Tahun 2009 Tentang Kepariwisataan 